Cybernetics: Journal Educational Research and Social Studies

Volume 2, Nomor 3, Juli 2021

Journal Homepage: http://pusdikra-publishing.com/index.php/jiss

\title{
Evaluasi Peningkatan Mutu Sekolah Melalui Pengembangan Profesionalisme Guru
}

\author{
Usiono, Rica Widiastuty, Azwardi
}

Universitas Islam Negeri Sumatera Utara

Corresponding Author : usiono@uinsu.ac.id

\begin{tabular}{ll}
\hline \multicolumn{1}{c}{ ABSTRACT } \\
\cline { 2 - 3 } & \multicolumn{1}{c}{ Pendidikan merupakan wadah pengembangan ilmu pengetahuan dan } \\
keterampilan agar peserta didik memiliki bekal keahlian dan memiliki \\
pemahaman serta pemikiran yang kritis. Peningkatan mutu pendidikan harus \\
selalu ada evaluasi terutama pada pengembangan profesionalisme guru. Mutu \\
pendidikan/sekolah sangat mempengaruhi peningkatan sumber daya manusia \\
yang lebih bermutu, memiliki wawasan yang luas, kreatif, mandiri, demokratis, \\
bertanggung jawab dan beriman serta bertaqwa kepada Tugan Yang Maha Esa. \\
$\begin{array}{l}\text { Pembangunan sumber daya manusia merupakan usaha setrategis yang harus } \\
\text { dilakukan pemerintah. Dalam penelitian ini bertujuan untuk meningkatkan } \\
\text { mutu sekolah dalam mengupayakan pengembangan guru professional agar } \\
\text { terwujudnya sekolah yang bermutu dari guru yang bermutu juga. Untuk } \\
\text { mewujudkan mutu sekolah harus ada evaluasi yang harus dilakukan pihak } \\
\text { sekolah dari berbagai manajemen dan pada penelitian ini yang akan diteliti } \\
\text { adalah pengembangan profesionalisme guru atau pendidik pada SD IT Al - } \\
\text { Manar. }\end{array}$ \\
\cline { 2 - 3 } Katu Pendidikan, Evaluasi, Profesionalisme Guru
\end{tabular}

\section{PENDAHULUAN}

Pembangunan nasional dalam bidang pendidikan ditujukan untuk mewujudkan upaya peningkatan mutu sumber daya manusia yang beriman, bertakwa, berpendidikan/ berilmu, menjadi manusia yang kreatif, mandiri dan menjadi warga negara yang demokratis juga bertanggung jawab. Hal ini sejalan degan hal yang diamanatkan dalam Undang - Undang Nomor 20 Tahun 2003 Bab 3 (pasal 3) tentang Sistem Pendidikan Nasional (UUSPN). Namun disinilah kelihatannya dunia pendidikan mengalami permasalahan yang bersifat multidimensi. Mulai dari rendahnya pemerataan pendidikan, rendahnya kualitas pendidikan, kurangnya manajemen pendidikan, minimnya alokasi anggaran pendidikan sampai dengan kurikulum dan pola pengajaran yang kurang sesuai dengan perkembangan zaman.

Hal yang menyebabkan rendahnya mutu pendidikan di Indonesia terletak pada masalah efektifitas, efisiensi dan standarisasi pengajaran, selain kurang kreatifnya para pendidik Saat ini dalam membimbing siswa kurikulum yang sentralistik membuat pendidikan semakin buram. Kurikulum dibuat hanya 
Cybernetics: Journal of Research and Educational Studies

Volume 2 Nomor 3, Juli 2021

Halaman 55-65

berdasarkan pengetahuan pemerintah tanpa memperhatikan kebutuhan masyarakat terutama pada masyarakat terpencil. Pendidikan di Indonesia belum mampu menghasilakan lulusan yang kreatif sehingga lulusan hanya mampu berkerja tetapi tidak mampu membangun lapangan pekerjaan. Berbagai upaya untuk peningkatan mutu pendidikan khususnya pendidikan dasar dan menengah mulai dari pelatiahan untuk meningkatkan kualitas guru, penyempurnaan kurikulum, perbaikan sarana dan prasarana sampai dengan peningkatan manajemen pendidikan. Hal lain yang yang menunjukan kualitas pendidikan diindonesia adalah rendahnya mutu guru sebagai seorang pendidik dalam semua jenjang pendidikan.

Mutu pendidikan merupakan hal utama yang harus diatasi dalam kebijakan pembangunan pendidikan, karena dengan pendidikan yang bermutu akan menghasilkan lulusan - lulusan yang bermutu yang mampu membangun diri, keluarga, masyarakat bangsa dan negara. Standar Nasional Pendidikan sudah menetapan peraturan pemerintah No.19 Tahun 2005, dan merupakan lanjutan dari Undang - undang Sistem Pendidikan Nasional, yang telah menentukan minimum bagi satuan pendidikan formal agar dapat memenuhi mutu pendidikan.

Lantas, apa itu mutu pendidikan? Mutu Pendidikan terdiri dari 2 kata yaitu mutu dan pendidikan. Dalam kamus bahasa Indonesia mutu adalah ukuran baik atau buruk suatu benda; taraf atau drajat (kepandaian, kecerdasan, kualitas dan sebagainya), sedangkan menurut J.M Juran, Mutu adalah kesesuaian memenuhi kebutuhan sekarang ataupun dimasa depan.

Sedangkan Pendidikan dapat diartikan sebagai proses menurut J.M Juran, pengubahan sikap dan tingkah laku seseorang atau kelompok manusia dalam usaha mendewasakan manusia itu sendiri melalui upaya pengajaran dan pelatihan. Jadi secara garis besar mutu pendidikan dapat diartikan sebagai kualitas (ukuran baik buruknya) Pendidikan.

Jadi salah satu penunjang baiknya mutu pendidikan adalah profesionalisme guru. Guru yang professional dapat diartikan sebagai profesi yang memiliki keahlian khusus untuk menjalankannya. Sedang professional dapat diartikan profesi yang memerlukan kepandaian khusus untuk menjalankannya. Ada 3 tugas guru sebagai profesi, yakni mengajar, mendidik dan melatih. Untuk dapat menjalankan tugas dan tanggung jawab tersebut seorang guru dituntut harus memiliki beberapa kemampuan dan kompetensi tertentu sebagai bagian dari profesionalisme guru. Kompetensi - kompetensi yang harus dimiliki seorang guru, yaitu kompetensi pedagogic. Kompetensi professional, kompetensi kepribadian dan kompetensi sosial. Jadi guru memiliki peranan yang sangat penting didalam menentukan kualitas pendidikan dan 
Cybernetics: Journal of Research and Educational Studies

Volume 2 Nomor 3, Juli 2021

Halaman 55-65

untuk membentuk guru yang professional perlu adanya evaluasi - evaluasi yang mendukung kompetensi yang harus dimiliki seorang pendidik.

Berdasarkan paparan diatas, peneliti sangat tertarik untuk meneliti lebih dalam tentang Evaluasi Peningkatan Mutu Sekolah Melalui Pengembangan Profesionalisme Guru. Peneliti bertujuan ingin mengetahui dan melihat secara terperinci bagai mana usaha sekolah dalam meningkatkan mutu sekolah di SD IT Al - Manar.

\section{METODE PENELITIAN}

Penelitian ini secara substantif mengunakan pendekatan kualitatif. sedangkan langkah yang ditempuh meliputi metode pengumpulan data dan metode analisi data hasil dari penelitian dituangkan pada pembahasannya.

\section{Metode Pengumpulan Data}

Data diperoleh dari sumbernya, yakni wawancara dengan bapak kepala sekolah, dan sebagai pendukungnya adalah buku dan jurnal. Ada dua sumber data peneliti gunakan disini yaitu sumber primer dan sumber sekunder. Sumber primer adalah sumber data yang terdapat informasi - informasi mengenai permasalahan yang dikaji. Dan data sekunder adalah buku dan jurnal yang digunakan sebagai refrensi yang informasi - informasi didalamnya masih memiliki korelasi dan relevansi dengan penelitian yang diteliti. Informasi yang didapat juga bisa berupa ulasan - ulasan penjelasan yang memili kaitan dengan tema yang diteliti.

Data juga didapat dari pengamat saya sebagai peneliti juga beberapa orang yang menanggapi tentang pertanyaan peneliti yang tidak secara langsung terbuka yaitu dari beberapa pengurus yayasan yang sangat ingin mutu pendidikan diyayasannya maju sesuai perkembangan dan ingin memiliki pendidik yg dibawa naungannya professional sesuai bidangnya.

\section{Metode Analisis Data}

Setelah data terkumpul dan terseleksi, kemudian diadakan proses analisis data yaitu memahami dan menafsirkan kumpulan informasi atau data yang diperoleh dengan cerman dan mendalam untuk memperoleh hasil yang sesuai dengan tujuan penelitian, data yang diperoleh dari hasil wawancara juga harus diobservasi. Dan perlu juga beberapa dokumentasi untuk menarik kesimpulan juga untuk mendapatkan data yang valid. 
Cybernetics: Journal of Research and Educational Studies

Volume 2 Nomor 3, Juli 2021

Halaman 55-65

\section{HASIL DAN PEMBAHASAN}

\section{Pengertian Evaluasi}

Evaluasi berasal dari bahasa inggris yakni evaluation yang artinya penilaian. Evaluasi atau penilaian adalah suatu usaha untuk mengetahui efektivitas pendukung pencapaian suatu program. Evaluasi juga merupakan proses yang tertata secara sistematis didalam menganalisis dan mengumpulkan data yang digunakan untuk mengambil keputusan dalam suatu program juga untuk mengukur dan melihat apakah ada peningkatan dalam suatu program, semakin baik atau tidaknya program tersebut. Selain itu evaluasi dalam suatu program juga dikembangkan dari berbagai manajemen atau pengelolahan yang lebih spesifik yakni evaluasi, monotoring dan kontrol.

Didalam dunia pendidikan evaluasi adalah kegiatan supervise sekolah (evaluasi program sekolah). Tujuan dari kegiatan evaluasi sekolah merupkan kegiatan penyusunan program untuk melihat pencapaian target sekolah.

Ada empat kebijakan yang dilakukan pihak sekolah untuk melaksanakan program evaluasi pada SD IT Al - Manar yakni:

1) Meningkatkan program untuk lebih baik lagi agar mutu pendidikan meningkat.

2) Memperbaiki program evaluasi jika ada hal - hal yang kurang sesuai.

3) Jika program sudah sesuai dengan yang diharapkan maka dapat dilanjutkan.

4) Mengembangkan program evaluasi yang sudah sesuai dan selulu di upgrade sesuai perkembangan pendidikan dan harus disebarluaskan program yang telah dicapai untuk dapat diterapkan disekolah lain.

Ada beberapa desain model evaluasi yang dibuat oleh parah ahli atau pakar evaluasi. Kaufan dan Thomas sebagaimana dikutip oleh Suharsimi Arikunto membedakan model evaluasi menjadi tujuh yakni:

1) Goald Orinted Evaluation Model : Objek pengamatan pada model ini adalah tujuan program yang telah ditetapkan jauh sebelum program evaluasi dimulai. Evaluasinya juga dilakukan dengan kesinambungan, terus menerus, mengecek seberapa jauh tujuan tersubut sudah terlaksana.

2) Goal Free Evaluation Model, Yang perlu diperhatikan dalam suatu program yakni bagaimana jalan kerjanya program evaluasi ini, dengan jalan mengidentifikasih hal - hal yang terjadi, baik hal - hal positif maupun hal - hal negatife (yang tidak diharapkan).

3) Formatif - Summatif Evaluation Model, Di Model ini menunjukan adanya tahapan dan ruang lingkup objek yang dievaluasi yakni pada 
waktu program masih berjalan (evaluasi formatif) dan evaluasi ketika program sudah berakhir (evaluasi sumatif).

4) Countenance Evaluation Model, Model ini dikemukakan oleh Stake. Model ini menekankan pada adanya pelaksanaan dua hal pokok, yakni: (1) Deskripsi (description) dan (2) Pertimbangan (Judgments), serta model ini membedakan adanya tiga tahap dalam program evaluasi yakni, (1) anteseden (antecedents/context), (2) transaksi (transaction/process), dan (3) Keluaran (output-outcomes).

5) CSE - UCLA Evaluation Model, Dimodel ini ada lima tahap yang dilakukan dalam evaluasi, yakni perencanaan, pengembangan, Implementasi, hasil dan dampak.

6) CIPP Evaluation Model, Model ini dikembangkan oleh Stufflebeam, dkk. Di Ohin University. CIPP merupakan singkatan dari, Context evaluation (evaluasi terhadap konteks), Input evaluation (evaluasi terhadap masukan), Proses evaluation (evaluasi terhadap proses, Product evaluation (evaluasi terhadap hasil). Dalam model ini tim evaluasi akan menganalisis program berdasarkan komponen komponenya.

7) Discrepancy Model, Model ini menekankan pada pandangan adanya kesenjangan didalam pelaksaan program. Evaluasi program dilakukan oleh evaluator mengukur besarnya kesenjangan disetiap komponen yang ada.

Model evaluasi yang digunakan pada SD IT Al - Manar saya lihat yaitu mendekati model CIPP. Alasannya, karena berdasarkan cara kerjanya memandang evaluasi adalah sebuah sistem dan tepat untuk pemprosesan seperti pengembangan profesionalisme guru dan pihak sekolah juga untuk mengevaluasi bagian - bagian yang terdapat dalam program pengembangan profesionalisme pendidik/guru. Peneliti lihat evaluasi yang dilakukan pihak sekolah termasuk juga pihak pengurus yayasan ikut berperan, yakni:

1) Evaluasi Konteks: adanya upaya untuk menggambarkan lingkunagan secara rinci, kebutuhan yang tidak terpenuhi, populasi dan sample juga tujuan proyek. Untuk membantu merencanakan pengambilan keputusan dan untuk menentukan kebutuhan yang akan dicapai oleh program serta merumuskannya (konteks nya adalah profesionalisme pendidik/guru).

2) Evaluasi Input (masukan): input pendidikan ialah segala sesuatu yang harus ada karena dibutuhkan untuk berjalannya proses pendidikan, seperti: Sumber daya manusia: guru, konsultan karyawan, peserta didik, wali murid, masyarakat dan sarana - prasarana dan juga dana. Input 
harapan: visi, misi dan tujuan yang ingin dicapai sekolah (evaluasi ini masuk dalam kinerja guru). Evaluasi dalam model ini mengarah pada kegiatan yang dilakukan didalam program dan kegiatan apa yang akan selesai. Jadi hal ini mengarah kepada seberapa jauh kegiatan dalam program terlaksana. Program evalusi yang dilakukan adalah MGMP, KKG, seminar pendidikan, diklat - diklat yang mengaju pada pendidikan dan kegiatan kecil lainnya yang mendukung proses pengembangan profesionalisme guru.

3) Evaluasi Hasil: mengarah pada hal yang menunjukan perubahan yang terjadi, hal ini dapat menolong keputusan selanjutnya.

Langkah evaluasi program: rancangan persiapan evaluasi program yang telah berjalan, mulai dari rancangan pelaksanaan hingga menuju monitoring.

\section{Mutu Sekolah}

Dalam kamus besar bahasa Indonesia mutu merupakan (ukuran) baik buruk suatu benda; taraf atau derajat (kepandaian, kecerdasan, dan sebagainya.); kualitas. Secara terminologi istilah mutu memiliki pengertian yang cukup beragam, mengandung banyak tafsir dan pertentangan. Hal ini disebabkan karena tidak ada ukuran yang baku tentang mutu itu sendiri. Sehingga sulit kiranya untuk mendapatkan sebuah jawaban yang sama, apakah sesuatu itu bermutu atau tidak. Namun demikian ada kriteria umum yang telah disepakati bahwa sesuatu itu di katakan bermutu, pasti ketika bernilai baik atau mengandung makna yang baik. Secara esensial istilah mutu menunjukan kepada sesuatu ukuran penilaian atau penghargaan yang diberikan atau dikenakan kepada barang dan atau kinerjanya. Menurut J.M Juran mutu adalah kesesuaian dengan tujuan atau manfaatnya. dan menurut W. Edward Deming, mutu harus bertujuan memenuhi kebutuhan pelanggan sekarang dan masa depan. Secara umum mutu dapat diartikan sebagai proses terstruktur untuk memperbaiki keluaran yang dihasilkan. Dalam konteks pendidikan, pengertian mutu mencakup input, proses, dan output pendidikan.

Input pendidikan adalah segala sesuatu yang harus tersedia karena dibutuhkan untuk berlangsungnya proses. Sesuatu yang dimaksud berupa sumber daya dan perangkat lunak serta harapan-harapan sebagai pemandu bagi berlangsungnya proses. Input pendidikan yang dimaksud disini seperti para pelaku pendidikan, sarana prasarana, uang, kurikulum dan sebagainya.

Proses pendidikan merupakan berubahnya sesuatu yang lain. Saat memulai suatu proses disebut input sedangkan hasil akhir dari proses itu disebut output. Maka proses pendidikan yang dimaksud disini adalah keadaan dimana 
para pendidik beserta stakeholders mendewasakan para peserta didik sehingga sesuai dengan tujuan pendidikan yang telah ditentukan.

Output pendidikan adalah merupakan kinerja sekolah. Kinerja sekolah adalah prestasi sekolah yang dihasilkan dari proses atau prilaku sekolah. Output sekolah dapat dikatakan berkualitas atau bermutu tinggi jika prestasi sekolah khususnya prestasi siswa, menunjukkan pencapaian yang tinggi dalam: (1) Prestasi akademik, berupa nilai ulangan umum, olimpiade sains, nilai ujian akhir,karya ilmiah, dan sebagainya.(2) Prestasi non-akademk, seperti kejujuran, kesopanan, olahraga, kesenian, keterampilan, kejuruan, dan kegiatan ekstrakulikuler lainnya.

Mutu pendidikan memiliki peranan yang begitu besar terkhusus di Sekolah Dasar (SD) dalam pencapaian tujuan pendidikan nasional. Tujuan pendidikan di Sekolah Dasar (SD) dalam aspek pelaksanaanya berbentuk bimbingan secara terpadu dan mengarahkan siswa untuk mencapai perubahan tingkah laku dan pemahaman menjadi lebih baik artinya lebih diutamakan pada pendewasaan diri. Jadi pendidikan merupakan proses belajar untuk menjadi berkarakter dan memiliki ilmu pengetahuan dan sosialisasi yang tinggi. Namun yang kita lihat pada saat ini adalah kualitas pendidikan diindonesia sangan memprihatinkan.

Hal ini disebabkan karena rendahnya mutu pendidikan diindonesia. Adapun masalah - masalah yang dihadapi pada umumnya seperti efektivitas, evisiensi, dan standarisasi pengajaran. Selain seorang pendidik kurang kreatif dalam membimbing siswa juga kurikulum yang sentralistik menjadikan pendidikan buram. Sehingga pendidikan tidak mampu menghasilakan lulusan yang kreatif. Masalah mendasar pendidikan diindonesia adalah ketidak seimbangan antara belajar yang berfikir (kognitif) dan belajar yang merasa (afektif). Belajar bukan hanya berfikir akan tetapi dapat melakukan banyak hal seperti mengamati, membandingkan, meragukan, menyukai, semangat, dan sebagainya.

Profesionalisme Guru

a) Pengertian Guru

Dalam Undang - Undang No. 14 Tahun 2005 tentang guru dan dosen (pasal 1) dinyatakan bahwa "Guru adalah pendidik profesinal dengan tugas utama mendidik, mengajar suatu ilmu, membimbing, mengarajkan, melatih, menilai dan mengevaluasi kepda pesera didik pada jalur pendidikan formal pada jenjang pendidikan dasar dan pendidikan menengah". Pengertian ini memberikan kesan bahwa guru adalah orang yang melakukan kegiatan dalam pendidikan. Adapun dari segi istilah telah banyak para ahli yang telah memberikan pengertian guru. Berikut ini akan dikemukakan beberapa pendapat ahli agar memberikan pemahaman yang lebih jelas sebagai berikut: 
Cybernetics: Journal of Research and Educational Studies

Volume 2 Nomor 3, Juli 2021

Halaman 55-65

Zahara Idris dan Lisma Jamal mengatakan bahwa guru (pendidik) adalah orang dewasa yang bertanggung jawab untuk memberikan bimbingan kepada peserta didik dalam perkembangan jasmani dan rohaninya, agar mencapai tingkat kedewasaan (mampu berdiri sendiri) memenuhi tugasnya sebagai makhluk tuhan, makhluk individu yang mandiri dan makhluk sosial.

Ramayulis berpendapat guru (pendidik) adalah orang yang memikul tanggung jawab untuk membimbing peserta didik menjadi manusia yang manusiawi.

Imam Barnadib menyebutkan bahwa guru (pendidik) adalah tiap orang yang dengan sengaja mempengaruhi orang lain untuk mencapai kedewasaan. Guru (pendidik) terdiri atas (1) Orang tua dan (2) orang dewasa lain yang bertanggungiawab tentang kedewasaan anak.

Ahmad D. Marimba mengatakan bahwa "pendidik adalah orang karena hak dan kewajibannya bertanggungiawab tentang pendidikan si terdidik.

Menurut al - Rasyidin Guru (pendidik) merupakan seorang yang memiliki ilmu pengetahuan tentang manusia, alam semesta, beserta seluruh mahluk ciptaan-Nya dan ia sendiri hidup dengan pengetahuan yang dimilikinya tersebut.

Dari pengertian diatas dapat disimpulakan bahwa guru (pendidik) adlah seseorang yang memiliki pendewasaan diri yang memiliki tugas utama mendidik, mengajar, membimbing, mengarahkan, melatih, menilai dan mengevaluasi pesertadidik mulai dari tahap pendidikan anak usia dini, pendidikan dasar, pendidikan menegah hingga tahapan universitas.

b) Syarat - Syarat Guru (pendidik)

Untuk menjadi guru (pendidik) ada beberapa syarat yng harus dimiiki: Dalam undang undang No. 20 tahun 2003 dan peraturan pemerintah RI No. 19 Tahun 2005 Bab VI tentang Standar pendidik dan tenaga Kependidikan memuat tentang persyaratan menjadi guru seperti dimuat pada pasal 28, yaitu:

Guru harus memiliki kualifikasi akademik dan kompetensi sebagai agent pembelajaran, sehat jasmani dan rohani, serta memiliki kemampuan untuk mewujudkan tujuan pendidikan nasional.

Kualifikasi akademik sebagaimana dimaksud pada ayat (1) tingkat pendidikan minimal yang harus dipenuhi oleh seorang guru yang dibuktikan dengan ijazah dan/atau sertifikat keahlian yang relevan sesuai ketentuan perundang - undangan yang berlaku. Kompetensi sebagai agen pembelajaran pada jenjang pendidikan dasar dan menengah serta pendidikan anak usia dini meliputi kompetensi pedagogik, kompetensi profesional, kompetensi kepribadian dan kompetensi sosial. Seorang yang tidak memiliki ijazah dan/atau sertifikat keahlian yang dimaksud pada ayat (2) tetapi memiliki 
Cybernetics: Journal of Research and Educational Studies

Volume 2 Nomor 3, Juli 2021

Halaman 55-65

keahlian khusus yang diakui dan diperlukan dapat diangkat menjadi guru setelah melewati uji kelayakan dan kesetaraan. Sedangkan berikut adalah beberapa persyaratan sebagai guru yang dikemukakan oleh beberapa ahli, yakni:

Abuddin Nata, secara garis besar menjelaskan ada tiga syarat khusus untuk profesi seorang pendidik, yaitu: Seorang guru yang profesional harus menguasai bidang ilmu pengetahuan yang akan diajarkannya dengan baik. Ia benar - benar seorang ahli dalam bidang ilmu yang diajarkannya dan selalu mengembangkan ilmu pengetahuannya secara terus - menerus. Seorang guru yang profesional harus memiliki kemampuan menyampaikan atau mengajarkan ilmu yang dimilikinya (transfer of knowledge) kepada kepada murid-muridnya secara efektif dan efisien. Untuk ini, seorang guru harus memiliki ilmu keguruan yang dahulu terdiri dari tiga bidang keilmuan yaitu pedagogik, didaktik, dan metodik. Seorang guru yang profesional harus berpegang teguh kepada kode etik profesi. Kode etik disini lebih dikhususkan lagi tekanannya pada perlunya memiliki akhlak yang mulia. Dengan akhlak mulia, seorang guru akan dijadikan panutan, contoh dan teladan.

\section{Pengembangan profesionalisme Guru (pendidik)}

Profesionalisme guru dapat dikembangkan sesuai instansi ataupun pribadi guru itu sendiri. Pengembangan guru dilakukan untuk merangsang, memelihara, dan meningkatkan kualitas staf dalam meningkatkan mutu sekolah dan dalam memecahkan masalah - masalah yang dihadapi dalam suatu instansi. Namun hal yang lebih penting dari hal ini adalah dasar dari kebutuhan guru untuk menjalani proses profesionalisme. Untuk itu perlu dikembangkan profesionalisme guru secara berkelanjutan mencakup kegiatan perencanaan, pelaksanaan, evaluasi, dan refleksi yang dibentuk untuk meningkatkan karakteristik, pengetahuan, pemahaman, dan keterampilan.

Peningkatan profesionalisme guru harus dilakukan secara sistematis dan direncanakan secara matang, dilaksanakan secara taat asas dan dievaluasi secara objektif. Ada beberapa upaya evalusi yang dapat dilakukan untuk meningkatkan profesionalisme guru, hasil wawancara dengan bapak kepala sekolah SD IT Al Manara:

1) Meningkatkan kualitas dan kemampuan dalam pelaksanaan proses pembelajaran

2) Berdiskusi tentang rencana pembelajaran

3) Berdiskusi tentang substansi meteri pembelajaran

4) Berdiskusi tentang pelaksanaan proses belajar mengajar termasuk evaluasi pengajaran

5) Melaksanakan observasi aktivitas rekan sejawat termasuk lewat organisasi profesi. 
Cybernetics: Journal of Research and Educational Studies

Volume 2 Nomor 3, Juli 2021

Halaman 55-65

6) Mengembangkan kompetensi dan performance

7) Mengkaji jurnal dan buku pendidikan

8) Mengikuti studi lanjut dan pengembangan melalui kegiatan ilmiah

9) Melakukan penelitian yang berkaitan dengan pendidikan dan pengajaran

10) Menulis Artikel

11) Mengikuti kegiatan seperti diklat, seminar, KKG (kelompok kerja guru) , PKG (pusat kegiatan guru) dan kegiatan lain yang mendukung pengembangan profesionalisme pendidik.

\section{KESIMPULAN}

Berdasarkan implikasi dari penelitian ini, peningkatan mutu sekolah/pendidikan sangat besar pengaruhnya dari pengembangan profesionalisme guru di SD IT Al - Manar. Pihak yayasan dan pihak sekolah SD IT Al - Manar sudah cukup baik dalam bekerja sama untuk meningatkan mutu sekolah didalam pengembangan profesionalisme guru. Banyak hal didalam manajemen sekolah yang selalu mereka evaluasi termasuk pendidiknya agar memproleh mutu sekolah yang berkualitas. Profesionalisme guru merupakan hal yang sangat penting dalam hal mendidik karena harus memiliki keahlian sesuai bidangnya sehingga kualitas pendidikan banyak ditentukan dengan kualitas pendidiknya. Banyak evalusi dalam mengembangkan profesionalisme guru. Dalam evalusi pengembangan profesinalisme guru seperti yang disampaikan bapak kepala sekolah SD IT AL - Manar banyak hal yang harus dilakukan dan evalusi sistemnya setelah berjalan apa yang telah dilakukan seperti terus meningkatakan kualitas pada pelaksanan proses pembelajaran, berdiskusi tentang sistem pembelajaran dan substansi materi pembelajaran, melakukan observasi pembelajaran teman sejawat ataupun melalui organisasi profesi, mengembangkan kompetensi dan performance, mengkaji jurnal dan buku-buku pendidikan untuk meningkatkan pengetahuan, dan mengikuti kegiatan - kegiatan seperti diklat, seminar, KKG, PKG dan kegiatan lainnya yang mendukung perkembangan profesionalisme guru. Evalusi pengembangan mutu sekolah di SD IT AL - Manar yang berkonsentrasi pada pengembangan profesionalisme guru selalu diupayakan semaksimal mungkin untuk menghasikan mutu seolah yang baik dari guru - guru yang bermutu. 
Cybernetics: Journal of Research and Educational Studies

Volume 2 Nomor 3, Juli 2021

Halaman 55-65

\section{DAFTAR PUSTAKA}

Egi Safitri (2019), Meningkatkan Mutu Pendidikan Melalui Supervisi Pendidikan Untuk Mencapai Kualitas Pendidikan Nasional, Hal 1- 4, Jurnal INA https://doi.org/10.31227/osf.io/x7cpg

Marsiti (2011), Upaya Peningkatan Mutu Pendidikan Sekolah Menengah Kejuruan Melalui Pengembnagan Profesionalisme Guru, Vol.1 (1), Hal 1 12, Jurnal Pendidikan avokasi.

https://doi.org/10.21831/jpv.v1i1.5810

Wirdatul Jannah (2021), Menjadi Guru Profesional: Memahami Hakikat dan

Kompetensi Guru, Hal. 1- 8, Jurnal OSF Preprints.

https://doi.org/10.31219/osf.io/fcq4t

Eka Prihatin,Teori Adminitrasi Pendidikan, Bandung: Alfabeta, 2014

Depdiknas, Kamus Besar Bahasa Indonesia edisi, Jakarta: Balai Pustaka, 2007

Ibrahim Bafadal, Peningkatan Profesionalisme Guru Sekolah Dasar, Jakarta: Bumi Aksara, 2014

Depdiknas, Kamus Besar Bahasa Indonesia edisi 3

Aan Komariah dan Cepi Triatna, Visionary Leadership: Menuju Sekolah Efektif, Jakarta: Bumi Akasara, 2008

Jarome S. Arcaro, Pendidikan Berbasis Mutu: Prinsip-Prinsip perumusan dan Tata Langkah Penerapan, terj. Yosai Triantara. Yogyakarta; Pustaka Pelajar, 2007

Zahara Idris dan Lisma Jamal, Pengantar Pendidikan, Jakarta: Grasindo, 1992

Ramayulis, Metodologi Pendidikan Agama Islam, Jakarta: Kalam Mulia, 2005

Sutan Imam Barnadib, Pengantar Ilmu Pendidikan Sistematis, Yogyakarta: Andiofrsct, 1993

Ahmad D. Marimba, Pengantar Filsafat Pendidikan Islam, Bandung: Al- Maarif, 1980

Al - Rasyidin, Falsafah Pendidikan Islami: Membangun kerangka Ontologi, Epistimologi, dan Aksiologi Praktik Pendidikan, Bandung: Citapustaka Media Perintis, 2008

Abuddin Nata, Managemen Pendidikan: Mengatasikelemahan pendidikan di Indonesia, Jakarta: Prenada Media, 2003

Salinah, Meningkatkan Mutu Pendidikan Melalui Supervisi Pendidikan".Jurnal Nasional, INA-Rxiv, 16 (Mei), https:/ / osf.io/preprints/inarxiv/ya63q/

Obsevasi dan Wawancara SD IT AL - Manar, Jl. Karya Bakti Kel. Pangkalan Masyhur Kec. Medan Johor, 25 Maret 2021

Artikel (https://085726012401.blogspot.com/2017/07/evaluasi-programpengembangan.html ) 